\title{
Penerapan Fungsi Manajemen dalam Pengelolaan Perpustakaan Madrasah Aliyah (Studi Kasus di Perpustakaan MAN 2 Palembang)
}

\author{
Rhoni Rodin ${ }^{1}$, Arif Dwi Santoso ${ }^{2}$, William Reinaldi ${ }^{3}$ \\ ${ }^{1}$ Insitut Agama Islam Negeri Curup \\ ${ }^{2}$ Universitas Islam Negeri Raden Fatah Palembang \\ ${ }^{3}$ Universitas Islam Negeri Raden Fatah Palembang \\ Email: rhoni.rodin@ iaincurup.ac.id
}

\begin{abstract}
The purpose of this study was to analyze how the application of management functions in the school library, especially in the MAN 2 Palembang's library. The research method used a descriptive approach with a qualitative analysis. Data collection techniques used were observation, interview and document study. The results showed that the MAN 2 Palembang library had implemented a management function in library management, which included planning, organizing, mobilizing, and controlling. However, there are still some aspects that should be improved. The MAN 2 Palembang library management planning process is more focused on user education that carried out in the new school year. Organizing the school library with the school library in general, which includes the form of organizational structure and the division of work of each library staff. The mobilization process related to the leadership process is carried out by the school principal and the job description is carried out based on the library head's instructions. Although there were no binding supervision standards, as a form of responsibility, the head of the library made a report every 6 months and the end of the school year that was delivered to the principal. However, there were still some obstacles that hamper the management process in the library; 1) The unavailability of computers and internet services to support the running of library management and services 2) not yet implemented the Islamic classification which should have been applied to the library of Islamic-based schools.
\end{abstract}

Keywords: Function of Management; School Library; MAN 2 Palembang's Library

\section{Abstrak}

Tujuan penelitian ini adalah untuk menganalisis bagaimana penerapan fungsi manajemen dalam perpustakaan madrasah khususnya di perpustakaan MAN 
2 Palembang. Metode penelitian menggunakan pendekatan deskriptif dengan analisis kualitatif. teknik pengumpulan data yang digunakan adalah observasi, wawancara dan studi dokumen. Hasil penelitian menunjukkan bahwa Perpustakaan MAN 2 Palembang telah menerapkan fungsi manajemen dalam pengelolaan perpustakaanya, yang meliputi perencanaan, pengorganisasian, penggerakan, dan pengawasan. Akan tetapi masih ada beberapa aspek yang harus d perbaiki. Proses perencanaan pengelolaan perpustakaan MAN 2 Palembang ini lebih difokuskan pada pendidikan pemakai yang dilaksanakan pada tahun ajaran baru. Pengorganisasian perpustakaan sekolah sama dengan perpustakaan sekolah pada umumnya, yang meliputi bentuk struktur organisasi serta pembagian kerja masingmasing staff perpustakaan. Proses penggerakan terkait proses kepemimpinan dilakukan oleh kepala sekolah dan job description yang dilakukan berdasarkan instruksi kepala perpustakaan. Meskipun tidak ada standar pengawasan yang mengikat, sebagai bentuk tanggung jawab maka kepala perpustakaan membuat laporan setiap 6 bulan dan akhir tahun ajaran yang disampaikan kepada kepala sekolah. Namun demikian, masih ada beberapa kendala yang menghambat proses manajemen di perpustakaan; 1) Belum tersedianya komputer dan layanan internet guna mendukung berjalannya pengelolaan dan pelayanan perpustakaan 2) belum diterapkannya klasifikasi Islam yang seharusnya telah diterapkan pada perpustakaan sekolah berbasis agama Islam ini.

Kata Kunci: Fungsi Manajemen; Perpustakaan Madrasah; Perpustakaan MAN 2 Palembang

\section{A. PENDAHULUAN}

Perpustakaan merupakan sebuah sarana penyedia informasi bagi pemustakanya. Perpustakaan sekolah/ madrasah pada dasarnya bertujuan untuk menyerap dan menghimpun informasi, sebagai wadah pengetahuan yang terorganisasi, menumbuhkan kemampuan menikmati pengalaman imajinatif, membantu perkembangan kecakapan bahasa dan daya pikir, mendidik siswa agar dapat menggunakan dan memelihara bahan pustaka secara efisien, serta memberikan dasar kearah studi mandiri. Oleh karena itu, untuk mewujudkan tujuan ini maka perpustakaan harus dikelola secara baik.

Perpustakaan sekolah/madrasah yang telah dimanajemeni dengan baik akan menarik minat siswa untuk memanfaatkan perpustakaan. Manajemen perpustakaan merupakan penerapan fungsi manajemen untuk memberdayakan unsur manajemen. Menurut Darmono, pada dasarnya hakikat manajemen secara sederhana adalah mengoptimalkan sumbangsih 
manusia, material, dan anggaran untuk mencapai tujuan organisasi yang telah ditetapkan. Perpustakaan semestinya dapat dijadikan tempat atau sarana untuk membantu membangkitkan semangat belajar, menumbuhkan dan meningkatkan minat baca, serta mendorong siswa agar terbiasa belajar secara mandiri, karena perpustakaan berfungsi sebagai sarana edukatif, informatif, riset, dan rekreatif. (Darmono, 2007 hal. 25).

Sebenarnya, pengelolaan perpustakaan bukanlah masalah baru namun masih banyak orang yang salah dalam memahami akan hakikat sebuah perpustakaan. Selama ini perpustakaan sering dipahami sebagai tempat tumpukan buku (Bafadal, 2009: 1). Tumpukan buku memang merupakan salah satu ciri dari suatu perpustakaan namun bukan berarti setiap ada penumpukan buku bisa disebut sebagai perpustakaan. Dalam artian yang spesifik, Perpustakaan digambarkan sebuah ruang khusus dan tata kerja yang khusus pula. Kesadaran pentingnya manajemen dalam perpustakaan adalah sebuah hal yang sangat diperlukan. Perpustakaan yang terorganisir dengan sistem manajemen memiliki sebuah nilai tambah dalam pelaksanaan perpustakaan. Agar kinerja perpustakaan lebih terarah dan peluang keberhasilan pencapaian tujuannya lebih besar. Pada umumnya, manajemen perpustakaan sekolah/madrasah di Indonesia masih mengalami berbagai hambatan, sehingga belum bisa berjalan sebagaimana yang diharapkan. Hambatan tersebut berasal dan dua aspek, yaitu pertama, aspek strutural, keberadaan perpustakaan sekolah kurang memperoleh perhatian dari pihak manajemen sekolah. Kedua, aspek teknis, dimana keberadaan perpustakaan sekolah masih belurn didukung aspek-aspek yang bersifat teknis yang sangat dibutuhkan oleh perpustakaan sekolah seperti tenaga, dana, serta sarana dan prasarana (Manajemen perpustakaan sekolah, 2007).

Dengan permasalahan di atas, peneliti memberikan batasan masalah pada penelitian ini agar lebih terarah dan tepat pada sasaran. Hal ini bertujuan agar hasil penelitian dapat dicapai secara optimal. Perpustakaan memiliki berbagai jenis kegiatan dalam kelangsungannya, namun pada penelitian kali ini peneliti memfokuskan untuk meneliti manajemen perpustakaan sekolah yang lebih di khususkan lagi kepada hal-hal yang meliputi perencanaan, pengorganisasian, staffing, directing, pengawasan serta pelaporan dalam perpustakaan sekolah dalam hal ini perpustakaan MAN 2 Palembang.

Ada beberapa penelitian yang pernah dilakukan berkaitan penerapan fungsi manajemen dalam pengelolaan perpustakaan sekolah menengah atas/ madrasah aliyah ini. Suhaemin \& Arikunto dalam penelitiannya di Perpustakaan MAN Yogyakarta menyimpulkan bahwa manajemen perpustakaan di tiga MAN Yogyakarta meliputi: a. Perencanaan meliputi 
pengadaan buku setiap tahun. b. Pengorganisasian perpustakaan MAN Y I berada dibawah wakil kepala madrasah bidang humas, MAN Y II berada di bawah wakil kepala madrasah bidang kurikulum dan MAN Y III berada di bawah kepala madrasah. c. Pelaksanaan mencakup pengadaan, pengolahan, pelayanan dan pembinaan. d. Pengawasan dilakukan secara langsung oleh kepala madrasah yang datang ke perpustakaan. Hambatannya adalah sarana perpustakaan yang masih kurang dan minat baca siswa yang masih rendah. Solusinya adalah berupaya melakukan penambahan sarana ruang baca, dan pemberian tugas kepada siswa agar perpustakaan (Manajemen perpustakaan di madrasah aliyah negeri Yogyakarta, 2013). Lebih lanjut Nihayati dalam penelitiannya menyimpulkan bahwa Perpustakaan MAN Kabupaten Bantul sebagian besar sudah sesuai dengan standar SNI 7329:2009 sebesar 52,27\%. Perpustakaan MAN Gandekan sudah sesuai dengan standar SNI 7329:2009 dengan prosentase sebesar 54,55\%. Selanjutnya Perpustakaan MAN Laboratorium UIN sudah sesuai dengan standar SNI 7329:2009 dengan prosentase sebesar 36,36\%. Kemudian Perpustakaan MAN Sabdodadi sudah memenuhi standar SNI 7329:2009 dengan prosentase sebesar 54,55\% dan Perpustakaan MAN Wonokromo pun sudah sesuai standar SNI 7329:2009 dengan prosentase sebesar $63,63 \%$. Penelitian ini menyarankan agar perpustakaan MAN di Kabupaten Bantul melakukan pembenahan diri agar dapat memenuhi standar SNI 7329:2009 tentang perpustakaan sekolah baik dalam hal pengembangan koleksinya, layanan perpustakaan, penyelenggaraan perpustakaan, anggaran perpustakaan, teknologi informasi di perpustakaan dan kerja sama perpustakaan dengan perpustakaan lain atau lembaga lain (Nihayati, 2013).

Kemudian Lubis dalam penelitiannya juga menjelaskan bahwa secara umum, manajemen Perpustakaan Madrasah Aliyah Negeri Pematangsiantar sudah berjalan cukup baik, meskipun masih ada kekurangannya. Beberapa hal yang membuat manajemennya dikata baik diantaranya sistem evaluasi manajemen yang dilakukan secara rutin mulai dari mingguan, bulanan, dan tahunan. Keberhasilan lainnya yakni tentang hubungan antar staf perpustakaan yang terjalin harmonis. Meskipun manajemen Perpustakaan Madrasah Aliyah Negeri Pematangsiantar cukup baik dalam hal kerjanya, namun tidak semuanya sesuai dengan ilmu manajemen dan tidak pula didasarkan kepada teori ilmu manajemen, jadi dalam hal ini lebih banyak berdasarkan pengalaman sehari-sehari saja (Lubis, 2019).

Adapun tujuan dari penelitian ini adalah untuk menganalisis penerapan fungsi manajemen perpustakaan di Perpustakaan MAN 2 Palembang dimulai dari segi perencanaan sampai segi kontrolingnya. Serta untuk mengetahui 
kendala atau permasalahan yang terjadi dalam manajemen perpustakaan di MAN 2 Palembang.

Teknik pengumpulan data yang digunakan dalam penelitian ini adalah observasi, interview dan studi dokumen. Bogdan mengatakan bahwa analisis data merupakan proses pencarian dan penyusunan secara sistematis data yang diperoleh dari hasil interview, catatan lapangan, dan bahan-bahan lain, sehingga dapat dipahami secara mudah, dan temuannya dapat diinformasikan kepada orang lain. Analisis data dilakukan dengan mengorganisasi data untuk selanjutnya ditampilkan dan dianalisis menjadi data yang lebih sederhana. Setelah proses pengumpulan data selesai, maka langkah selanjutnya adalah mengolah data tersebut.

Berdasarkan uraian di atas maka penulis tertarik untuk menganalisis bagaimana penerapan fungsi manajemen dalam pengelolaan perpustakaan di MAN 2 Palembang dan apa saja kendala yang dihadapi dalam proses manajemen perpustakaan di MAN 2 Palembang.

\section{B. HASIL DAN PEMBAHASAN}

\section{Pengertian Perpustakaan Sekolah/ Madrasah}

Secara etimologi, kata perpustakaan berasal dari kata pustaka, yang mempunyai arti kitab atau buku. Kemudian ditambah awalan per- dan akhiran -an sehingga kata perpustakaan mempunyai arti kumpuan buku-buku yang lebih dikenal sebagai koleksi bahan pustaka. Perpustakaan dalam bahasa Belanda dan Jerman disebut bibliothek, dalam bahasa Prancis disebut bibliotheque, sedangkan dalam bahasa Inggris disebut library, yang sebenarnya berasal dari bahasa Latin yaitu liber atau libri yang artinya buku.

Menurut IFLA (International Federation of Library Association and Institutions) bahwa perpustakaan merupakan kumpulan bahan cetak dan noncetak dan atau sumber informasi dalam komputer yang disusun secara sistematik untuk kepentingan pemakai. Undang-Undang Republik Indonesia Nomor 43 tahun 2007 pasal 1 menjelaskan bahwa perpustakaan adalah institusi pengelola koleksi karya tulis, karya cetak, dan atau karya rekam secara profesional dengan sistem yang baku guna memenuhi kebutuhan pendidikan, penelitian, pelestarian, informasi dan rekreasi para pemustaka. Sedangkan pada pasal 4 menyatakan bahwa tujuan diselenggarakannya perpustakaan adalah untuk memberikan layanan kepada pemustaka, meningkatkan minat dan budaya baca serta untuk memperluas wawasan dan pengetahuan untuk mencerdaskan kehidupan bangsa. 
Jadi dapat dipahami bahwa perpustakaan merupakan suatu lembaga penyebar informasi yang dilaksanakan atas dasar pengelolaan koleksi bahan pustaka baik yang tercetak maupun non cetak dengan sistem yang telah ditetapkan sesuai dengan standar yang berlaku serta memiliki fungsi dan kegunaan untuk dimanfaatkan pada saat ini maupun masa yang akan datang.

Berdasarkan Undang-undang Nomor 43 tahun 2007, perpustakaan sekolah merupakan salah satu dari jenis perpustakaan. Menurut Carter V Good (dalam Ibrahim Bafadal) bahwa perpustakaan sekolah mempunyai definisi sebagai koleksi yang diorganisasikan di dalam suatu ruangan agar dapat digunakan oleh murid-murid dan guru-guru yang dalam penyelenggaraannya diperlukan seorang pustakawan yang bisa diambil dari salah seorang guru (Bafadal, 2015 hal. 4). Kemudian berdasarkan Standarisasi Nasional Perpustakaan bahwa perpustakaan sekolah adalah perpustakaan yang berada pada satuan pendidikan formal di lingkungan pendidikan dasar dan menengah yang merupakan bagian integral dari kegiatan sekolah yang bersangkutan, dan merupakan pusat sumber belajar untuk mendukung tercapainya tujuan pendidikan sekolah yang bersangkutan (Perpustakaan Nasional Republik Indonesia).

Perpustaakaan sekolah merupakan salah satu sarana dan fasilitas penyelenggaraan pendidikan, sehingga setiap sekolah seharusnya mempunyai perpustakaan yang memadai. Perpustakaan sekolah berada pada lingkungan sekolah, dan penanggung jawabnya adalah kepala sekolah, dan biasanya yang mengelola perpustakaan adalah guru dan pegawai yang ditugaskan oleh kepala sekolah (NS, 2006 hal. 40).. Perpustakaan sekolah mempunyai pengaruh kuat terhadap keberhasilan kegiatan belajar mengajar di sekolah, ungkapan "Perpustakaan sebagai Jantung Pendidikan" memang benar adanya, perpustakaan dapat meningkatkan kualitas dan keilmuan siswa di sekolah. Engking Mudyana dan Royani, sebagaimana dikutip oleh Sinaga di dalam buku Andi Prastowo mengatakan bahwa perpustakaan sekolah merupakan salah satu sarana penunjang pendidikan yang berfungsi sebagai pelestari ilmu pengetahuan, dan di sisi lain sebagai pusat sumber belajar yang akan diwariskan kepada generasi selanjutnya (Prastowo, 2013 hal. 55).

Berdasarkan beberapa pengertian yang diungkapkan oleh para ahli perpustakaan dapat kita ambil kesimpulan bahwa perpustakaan sekolah adalah sebagai sebuah instansi yang ikut andil daam pelaksanaan kegiatan belajar dan mengajar di sekolah serta berperan penting dalam usaha mencerdaskan para siswa dengan menyediakan berbagai koleksi yang di butuhkan para siswa dalam proses belajarnya. Sehingga dapat tercapainya tujuan pendidikan sekolah. 


\section{Tujuan dan Fungsi Perpustakaan Sekolah/ Madrasah}

Perpustakaan sekolah dibangun untuk membantu setiap masyarakat di lingkungan sekolah, perpustakaaan sekolah tidak hanya sebagai pelengkap akan akreditasi dari sekolah tersebut. Perpustakaan sekolah sebagai salah satu instansi yang berintegrasi dengan sekolah diharapkan mampu menunjang terhadap pencapaian tujuan sekolah. Sehubungan dengan hal tersebut, perpustakaan sekolah mempunyai tujuan yaitu: (Prastowo, 2013 hal. 50)

a. Memberikan dorongan dan percepatan proses penguasaan teknik membaca para siswa.

b. Membantu siswa dalam menulis kreatif dengan bimbingan guru dan pustakawan.

c. Menumbuhkembangkan minat dan budaya baca para siswa.

d. Menyediakan bermacam-macam sumber informasi untuk kepentingan pelaksanaan kurikulum.

e. Mendorong, menggairahkan, memelihara, dan memberi semangat membaca dan belajar kepada para siswa.

f. Memperluas, memperdalam, dan memperkaya pengalaman belajar para siswa dengan membaca buku dan koleksi lain yang mengandung ilmu pengetahuan dan teknologi yang disediakan oleh perpustakaan.

g. Memberikan hiburan sehat bagi para siswa untuk mengisi waktu senggang melalui kegiatan membaca, khususnya buku-buku dan sumber bacaan lain yang bersifat kreatif dan ringan, misalnya fiksi, cerpen, dan lain sebagainya.

Menurut Ibrahim Bafadal dalam bukunya yang berjudul Pengelolaan Perpustakaan Sekolah, ada beberapa fungsi perpustakaan sekolah antara lain: (Bafadal, 2015 hal. 6-8).

1. Fungsi Edukatif

Di dalam perpustakaan sekolah tersedia berbagai buku baik buku-buku fiksi maupun non fiksi. Adanya buku-buku tersebut tentunya dapat membiasakan murid-murid untuk belajar secara mandiri tanpa bimbingan guru, baik secara individual maupun berkelompok. Selain itu di dalam perpustakaan sekolah juga tersedia buku-buku yang sebagian besar pengadaannya mengakomodir kebutuhan kurikulum sekolah.

2. Fungsi Informatif

Pada fungsi ini, perpustakaan tidak hanya menyediakan bahan-bahan pustaka yang hanya berupa buku-buku, akan tetapi juga menyediakan bahan-bahan yang berupa non buku (non book material) seperti majalah, bulletin, surat kabar, pamflet, guntingan artikel, peta, bahkan dilengkapi 
dengan alat-alat pandang-dengar seperti overhead projector, televisi, video tape recorder dan sebagainya.

3. Fungsi Tanggung Jawab Administratif

Fungsi ini tampak pada kegiatan sehari-hari di perpustakaan sekolah, di mana setiap ada peminjaman dan pengembalian buku selalu dicatat oleh petugas perpustakaan. Setiap murid yang akan masuk ke perpustakaan harus menunjukan kartu anggota atau kartu pelajar serta berbagai peraturan lainnya yang harus di patuhi oleh para siswa. Semua hal tersebut, selain mendidik murid-murid ke arah tanggung jawab, juga membiasakan murid-murid bersikap dan bertindak secara administratif.

4. Fungsi Riset

Tersedianya bahan pustaka yang lengkap tentunya akan mendukung para murid dan guru dalam melakukan riset, yaitu mengumpulkan data atau keterangan-keterangan yang diperlukan.

5. Fungsi Rekreatif

Fungsi ini tidak berarti bahwa secara fisik pergi mengunjungi tempattempat tertentu, akan tetapi fungsi ini lebih bersifat secara psikologis. Sebagai contoh, ada seorang murid yang membaca buku yang berjudul "MALANG KOTA INDAH". Dengan demikian murid yang membaca buku tersebut secara psikologis akan terbawa rekreasi ke kota Malang yang indah itu. Selain itu, fungsi rekreatif berarti bahwa perpustakaan sekolah dapat dijadikan sebagai tempat mengisi waktu luang seperti pada waktu istirahat, dengan membaca buku-buku cerita, novel, roman, majalah, surat kabar, dan sebagainya.

Berdasarkan uraian diatas, dapat kita simpulkan bahwa fungsi dari perpustakaan sekolah/madrasah tidak hanya sebagai instansi penyebar informasi semata, tetapi juga berfungsi sebagai instansi pembelajaran/pendukung dalam penciptaan kreasi siswa, sebagai pembentuk karakter, dan juga sebagai media hiburan yang bersifat positif.

\section{Pengertian Manajemen Perpustakaan}

Perpustakaan sekolah sebagai suatu unit informasi tentunya akan memiliki kinerja yang baik apabila dikelola dengan baik. Dengan adanya manajemen, kegiatan perpustakaan sekolah akan mencapai tujuan yang telah ditetapkan. Untuk mencapai tujuan, maka perpustakaan sekolah perlu menata kegiatan yang akan dikerjakan oleh perpustakaan. Penataan itulah yang disebut manajemen. Dalam proses manajemen ada perencanaan, pengorganisasian, penganggaran, kepemimpinan, dan pengawasan. 
Pengertian manajemen sendiri sebenarnya telah banyak dibahas oleh para ahi. Diantaranya, menurut Zulkifli Amsyah (2001:1) manajemen merupakan proses kegiatan mengelola sumber daya manusia, materi, dan metode berdasarkan fungsi-fungsi manajemen agar tujuan dapat dicapai secara efesien dan efektif (HS, 2009 hal. 17).

Sementara itu, Luther Gullick memberikan definisi manajemen sebagai suatu bidang ilmu pengetahuan/science yang berusaha secara sistematis untuk memahami mengapa dan bagaimana manusia bekerja bersama untuk mencapai tujuan yang telah ditetapkan dan membuat sistem kerjasama ini lebih manfaat bagi kemanusiaan. (HS, 2009 hal. 17)

Kemudian Kamus Besar Bahasa Indonesia (KBBI) menjelaskan bahwa manajemen adalah (1) manajemen merupakan suatu proses penggunaan sumber daya secara efektif untuk mencapai sasaran; (2) manajemen merupakan pejabat atau pimpinan yang bertanggung jawab atas jalannya perusahaan (Abdul Rahman Saleh, 2013 hal. 1.24).

Berdasarkan pengertian diatas, dapat kita simpulkan manajemen perpustakaan merupakan suatu usaha kegiatan yang dapat menciptakan tujuan yang ingin dicapai tercapai secara efektif dan efisien. Manajemen juga dapat diartikan sebagai sebuah pengaturan sistematika perpustakaan yang dilakukan oleh kepala perpustakaan dalam penentuan orang-orang yang dapat mengemban tanggung jawab atas berjalannya sebuah instansi atau perusahaan. Pengelolaan sebuah perpustakaan tidak semudah membalikkan tangan, akan tetapi memerlukan kemampuan manajerial yang baik, agar arah kebijakan dan kegiatan sesuai dengan tujuan yang telah ditetapkan. Kemampuan manajemen tersebut juga diperlukan untuk menjaga keseimbangan tujuan-tujuan yang berbeda sehingga bisa dilaksanakan secara efektif dan efisien. Oleh karena itu, manajemen sangat diperlukan dalam berbagai kehidupan untuk mengatur langkah-langkah yang harus dilaksanakan oleh seluruh elemen perpustakaan (Rodin, 2018).

\section{Fungsi Manajemen Perpustakaan}

Manajemen perlu diadakan di perpustakaan demi terciptanya sebuah perpustakaan yang terstruktur dan yang berjalan dengan semestinya. Koontz dan O'Donnell menjelaskan bahwa fungsi manajemen ada lima, meliputi planning, organizing, staffing, directing, dan controlling (Abdul Rahman Saleh, 2013 hal. 1.35).

Sistem manajemen yang teratur dengan baik akan membuat sebuah perpustakaan menjadi lebih terstruktur dan mudah untuk diperbaiki jika 
terjadi kejanggalan dan kerusakan. Kelima sistem manajemen yang telah disebutkan diatas menunjukan sebuah jalan sistem dimana manajemen nya dimulai sari perencanaan sampai kepada kontrol kepada para pengguna perpustakaan.

\section{Sejarah Singkat Perpustakaan MAN 2 Palembang}

Perpustakaan MAN 2 berdiri semenjak sekolah ini masih bernama S.P. IAIN hanya saja perpustakaan ini berupa ruangan kecil yang dijadikan satu dengan tempat penyimpanan beras yang pada saat itu luas gedung hanya berukuran $5 \mathrm{X} 3$ meter, dengan koleksi buku yang sangat sedikit, kalaupun ada siswa yang ingin membaca di ruangan perpustakaan tidak akan memberikan kenyamanan yang maksimal, karena harus berhimpitan dengan lemari buku. Pada tahun 1990 sampai 2003, perpustakaan MAN 2 Palembang mulai terpisah dengan ruang penyimpanan beras dan berpindah ke ruangan kelas sampai berkali-kali sampai tahun 2009, dan itu pun telah mengalami perpindahan sebanyak 5 kali. Pada tahun 2010 perpustakaan MAN 2 Palembang berpindah gedung sendiri dengan luas gedung $63 \mathrm{~m}^{2}$. Perpustakaan ini terdiri dari beberapa ruangan yaitu, ruang kepala perpustakaan, ruang baca, ruang pelayanan (sirkulasi), dan ruang koleksi. Pada waktu itu jumlah koleksi buku masih sedikit dan pengadaan bahan bacaan pada saat itu, masih mengutamakan pengadaan buku paket dan buku pegangan siswa.

Hingga kini pergantian Kepala Perpustakaan yang bertugas di MA Negeri 2 Palembangini sebanyak 8 kali diantaranya:

1. Ibu Cek Esa

2. Ibu Dra. Rasuna

3. Ibu Nurhayati, Ama.

4. Ibu Titin Suryani, S.Pd.

(1984)

5. Ibu Yulia Supriani, Ama.

(2000-2003)

6. Ibu Dra.Komaria, M.Pd.

7. Ibu Dra. Fatriana Mahdan

8. Ibu Dra. Lismawati Rodhiah

(2003- 2006)

(2007-2009)

(2010-2011)

(2011-2012)

(2012-sekarang)

\section{Penerapan Fungsi Manajemen di Perpustakaan MAN 2 Palembang}

Pada dasarnya manajemen sangat diperlukan dalam berbagai kehidupan terutama untuk mengatur langkah-langkah yang harus dilakukan oleh seluruh elemen perpustakaan (Rodin, 2018). Kemampuan manajemen juga dibutuhkan untuk menjaga keseimbangan di antara tujuan-tujuan yang berbeda sehingga bisa dilaksanakan secara efektif dan efisien. Berdasarkan 
data penelitian tentang manajemen MAN 2 Palembang ini dimulai sejak berlakunya tahun ajaran baru, dimana para Perpustakaan Madarasah di MAN 2 Palembang diperoleh gambaran sebagai berikut.

1. Manajemen Perpustakaan Madrasah

Manajemen perpustakaan di MAN 2 Palembang terdiri dari perencanaan, pengorganisasian, penggerakan dan pengawasan. Adapun penerapan fungsi manajemen di Perpustakaan MAN 2 Palembang sebagai berikut:

a. Perencanaan Manajemen Perpustakaan di MAN 2 Palembang

Perencanaan merupakan starting point berbagai aktivitas organisasi yang sangat menentukan keberhasilan organisasi. Perencanaan berfungsi untuk memberikan arah, menjadi standar kerja, memberikan kerangka pemersatu, dan membantu memperkirakan peluang dari pelaksanaan manajemen perpustakaan.

Berdasarkan hasil wawancara peneliti dengan ibu Lismawati Rodhiah selaku kepala perpustakaan, dalam perencanaan manajemen perpustakaan sekolah MAN staf melakukan sejenis pendidikan pemakai untuk memberikan pemahaman kepada siswa baru mengenai perpustakaan, mulai dari persyaratan menjadi anggota serta bagaimana cara kita bisa memanfaatkan perpustakaan dengan maksimal.

Perencanaan manajemen perpustakaan sekolah di MAN 2 Palembang ini dimulai dengan mempersiapkan petugas perpustakaan dalam memberikan pelayanan, koleksi bahan pustaka, kesiapan staf dalam pengolahan bahan pustaka, penganggaran, dan pengadaan fasilitas pendukung pelaksanaan manajemen perpustakaan sekolah.

b. Bentuk layanan

Berdasarkan hasil observasi yang dilakukan peneliti pada 14 Mei 2018, perpustakaan MAN 2 Palembang menerapkan sistem terbuka bagi layanan yang ada di perpustakaan. Dalam layanan terbuka, perpustakaan MAN 2 Palembang memberikan kebebasan bagi para pemustaka untuk dapat masuk dan memilih sendiri bahan pustaka yang mereka butuhkan dalam setiap rak. Hal ini sesuai dengan yang disampaikan oleh ibu Lismawati Rodhiah selaku Kepala Perpustakaan sekaligus sebagai key informan dalam wawancara yang dilakukan di perpustakaan MAN 2 Palembang yang dilaksanakan pada 14 Mei 2018 bahwa perpustakaan sekolah 
menggunakan sistem layanan terbuka. Hal ini dilakukan guna menghadirkan rasa nyaman bagi setiap pemustaka yang masuk keperpustakaan, memaksimalkan fungsi serta kegunaan sumber bahan pustaka dan juga karena keterbatasan tenaga perpustakaan yang tidak memungkinkan untuk melayani kebutan pemustaka/siswa dengan sistem tertutup.

c. Kesiapan staf dalam pengolahan bahan pustaka

Hasil observasi peneliti menunjukan bahwa kesiapan tenaga perpustakaan dalam pengolahan bahan pustaka terkait dengan pelaksanaan manajemen perpustakaan sekolah dapat dikatakan sudah cukup baik. Dimana dalam proses pengolaan bahan pustakanya, para staf saling bekerjsama dalam melaksanakan kegiatan pengolaan bahan pustaka tersebut. Jadi, mereka saling bantu membantu serta sama-sama bersinergi dalam pelaksanaan kegiatan tersebut.

Proses pengolahan bahan pustaka di Perpustakaan MAN 2 Palembang antara lain:

1) Buku diterima, kemudian dipilih berdasarkan subjeknya utnuk memudahkan proses klasifikasi.

Buku yang datang ke perpustakaan kemudian dipilah terlebih dahulu untuk mempermudah proses selanjutnya yakni proses pengklasifikasian. Sistem pengklasifikasiaan di perpustakaan MAN 2 Palembang ini menggunakan sistem Dewey Decimal Classification (DDC). Kepala Perpustakaan mengemukakan alasan penggunaan DDC adalah karena mengikuti sistem-sistem para Kepala Perpustakaan sebelumnya. Jadi walaupun klas untuk notasi agama Islam itu sudah dibedakan menjadi klas 2X0-2X9 akan tetapi manajemen perpustakaan MAN 2 Palembang ini masih menggolongkannya kepada klas 200 saja.

2) Inventarisasi

Setelah pengklasifikasian, langkah selanjutnya adalah inventarisasi. Inventarisasi bahan pustaka merupakan kegiatan pencatatan setiap bahan pustaka yang dikelola ke dalam buku inventaris yang menyangkut semua data informasi yang sesuai dengan kebutuhan perpustakaan. Berdasarkan hasil observasi peneliti, pencatatan bahan pustaka dilakukan dalam buku induk. 
3) Cap/stempel

Cap/ stempel perpustakaan, barisi nama dan simbol perpustakaan yang dicap pada halaman awal, akhir, tengah, dan pinggir buku.

4) Labelisasi

Labelisasi termasuk salah satu kelengkapan sebelum bahan pustaka disajikan. Label buku ditempel di punggung buku bagian bawah dengan ukuran $3 \mathrm{~cm} \mathrm{x} 4 \mathrm{~cm}$ atau menyesuaikan dengan ketebalan buku dengan jarak $\pm 2-3 \mathrm{~cm}$ dari bawah. Pada label dicantumkan kode yang memuat nomor klasifikasi, 3 (tiga) huruf pertama nama pengarang (tajuk entri utama) dan 1 (satu) huruf awal judul buku.

5) Pembuatan Kartu Katalog

Kartu katalog merupakan sebuah dokumen ringkas yang harus ada dalam proses pengadaan buku sebelum buku-buku yang ada tersebut kemudian disusun dalam rak masing-masing. Kartu katalog yang dibuat mencakup:

1. Daerah 1

2. Daerah 2

3. Daerah 3

4. Daerah 4

5. Daerah 5

6. Daerah 6

7. Daerah 7

8. Daerah 8
: Judul dan pernyataan tanggung jawab

: Cetakan/Edisi

: Data khusus

: Tempat terbit/tahun/penerbit

: Deskripsi fisik

: Seri

: Catatan

: ISBN

Yang kemudian dicantumkan dalam kartu katalog yang berukuran $12 \mathrm{~cm}$ x $7 \mathrm{~cm}$. Untuk membantu para siswa menemukan buku yang mereka cari. Berdasarkan hasil penelitian, proses katalogisasi di Perpustakaan MAN 2 Palembang ini menerapkan sistem kerjasama antar staf sehingga pekerjaannya bisa terlaksana dengan baik dan mudah.

6) Membuat kelengkapan lainnya seperti kantong buku

Kemudian tahap terakhir pengolahan bahan pustaka adalah melengkapi bahan pustaka dengan kelengkapan fisik seperti kantong buku. Kantong buku terbuat dari kertas samson warna coklat atau kertas buram dan ditempel di lembar buku paling 
belakang bagian bawah. Kantong buku digunakan sebagai tempat penyimpanan kartu buku. Kartu buku berfungsi bila buku dipinjam, data peminjam tertulis pada kartu tersebut, lalu kartu buku tersebut disimpan pada kotak yang disediakan. Kartu buku terbuat dari kertas HVS. Kantong buku ini dibutuhkan ketika perpustakaan menerapkan layanan secara manual. Akan tetapi bila perpustakaan telah menerapkan sistem otomasi, maka kantong buku ini tidak begitu diperlukan, sebab data peminjam sudah tersimpan dalam server.

Berdasarkan hasil observasi peneliti, bahan pustaka yang disediakan oleh Perpustakaan MAN 2 Palembang meliputi dari buku paket, fiksi, non fiksi dan referensi. Hal ini sesuai dengan dokumen Jenis dan Jumlah Koleksi Perpustakaan MAN 2 Palembang . Akan tetapi, menurut pemaparan Kepala Perpustakaan bahwasanya data-data buku tersebut belum sepenuhnya dimasukan kedalam buku induk.

Tabel 1. Koleksi Perpustakaan MAN 2 Palembang

\begin{tabular}{|c|l|c|}
\hline No & \multicolumn{1}{|c|}{ Jenis Buku } & Jumlah Judul \\
\hline 1 & Referens & 80 \\
\hline 2 & Paket & 21 \\
\hline 3 & Fiksi & 54 \\
\hline 4 & Non Fiksi \\
& $000-090$ & 42 \\
& $100-190$ & 13 \\
& $200-290$ & 448 \\
& $300-390$ & 99 \\
& $400-490$ & 42 \\
& $500-590$ & 56 \\
& $600-690$ & 157 \\
& $700-790$ & 54 \\
& $800-890$ & 28 \\
& $900-990$ & 23 \\
\hline
\end{tabular}

Sumber: Data koleksi Perpustakaan MAN 2 Palembang tahun 2018

d. Pengorganisasian Manajemen Perpustakaan di MAN 2 Palembang

Pengorganisasian merupakan penyatuan langkah dari seluruh kegiatan yang akan dilaksanakan oleh elemen-elemen dalam suatu lembaga. Pengorganisasian ini sangat penting perannya untuk menghindarkan tumpang tindih dalam pelaksanaan tugas. Suatu 
organisasi tanpa struktur organisasi dapat dikatakan tidak berjalan dengan baik, karena akan terjadi ketimpangan dalam melaksanakan tugas kepustakaan. Sehingga menurut Stueart, pengorganisasian itu terdiri dari penetapan apa saja tugas yang harus dilakukan, siapa yang melakukannya, bagaimana tugas dikelompokkan, dan bagaimana semua tugas dikoordinasikan. Pada akhirnya, hasil dari pengorganisasian ini adalah pembentukan struktur organisasi.

1) Pembagian Tugas

Petugas perpustakaan MAN 2 Palembang semula berjumlah empat orang. Akan tetapi menurut informasi dari kepala perpustakaan MAN 2 Palembang yang didapat melalui wawancara yang dilakukan pada tanggal 21 November 2017 diruang perpustakaan bahwasanya belum lama ini seorang staff perpustakaan di Perpustakaan MAN 2 Palembang tidak lagi bekerja sebagai staff di perpustakaan tersebut. Sehingga petugas perpustakaan di MAN 2 Palembang kini berjumlah tiga orang yang mana pembagian tugas staff perpustakaan MAN 2 Palembang dilakukan oleh Kepala Perpustakaan. Pembagian kerja para staff disesuaikan dengan kompetensi yang dimiliki oleh masing-masing staff, sehingga pekerjaan yang ditugaskan dapat dilaksanakan dengan baik dan mendapatkan hasil yang memuaskan. Uraian tugas personalia Perpustakaan MAN 2 Palembang, antara lain:

2) Tugas Kepala Perpustakaan

a. Mengkoordinir kegiatan atau tugas kerja personil perpustakaan.

b. Menyusun program kerja tahunan.

c. Mengawsi kerja personal perpustakaan.

d. Konsultasi dengan Kepala Sekolah

e. Menyeleksi buku yang akan dibeli bersama dengan pihak terkait.

f. Bertanggung jawab atas kemajuan dan perkembangan perpustakaan.

g. Membuat laporan pertanggung jawaban atas pelaksananaan program kerja pada akhir tahun ajaran.

h. Mengatur ruangan perpustakaan.

i. Menentukan sistem pengolahan dan pelayanan perpustakaan.

j. Menentukan syarat-syarat keanggotaan perpustakaan. 
k. Melakukan korespondensi dengan perpustakaan lain untuk mengadakan kerjasama.

3) Tugas Tenaga Administrasi

a. Membantu layanan sirkulasi dan prosesing buku koleksi.

b. Mengatur buku dalam rak menurut klasifikasinya.

c. Pendataan koleksi.

d. Membuat kartu katalog dan memasangnya.

e. Urusan surat menyurat.

f. Membuat data jumlah buku baik buku hadiah maupun buku pembelian.

g. Mengadakan inventarisasi bahan pustaka.

4) Tugas Pelayanan Teknis

a. Menyediakan peralatan administrasi perpustakaan.

b. Menginventarisasi dan prosesing buku koleksi.

c. Membantu layanan sirkulasi dan administrasi perpustakaan.

d. Meneliti buku-buku yang rusak, kurang lengkap, robek, ada coret-coretannya dan memperbaikinya.

e. Melayani peminjaman, perpanjangan, dan pengembalian buku.

f. Mencatat daftar peminjaman dan pengembalian buku.

g. Menerima dan menertibkan uang denda.

h. Mendaftar anggota perpustakaan.

i. Menyediakan buku daftar hadir.

j. Memberi peringatan kepada anggota (peminjaman buku) yang melewati batas waktu.

5) Bagan Organisasi

Berdasarkan hasil wawancara peneliti dengan Kepala Perpustakaan pada tanggal 14 Mei 2018, diketahui bahwa bagan organisasi Perpustakaan MAN 2 Palembang, sebagai berikut: 


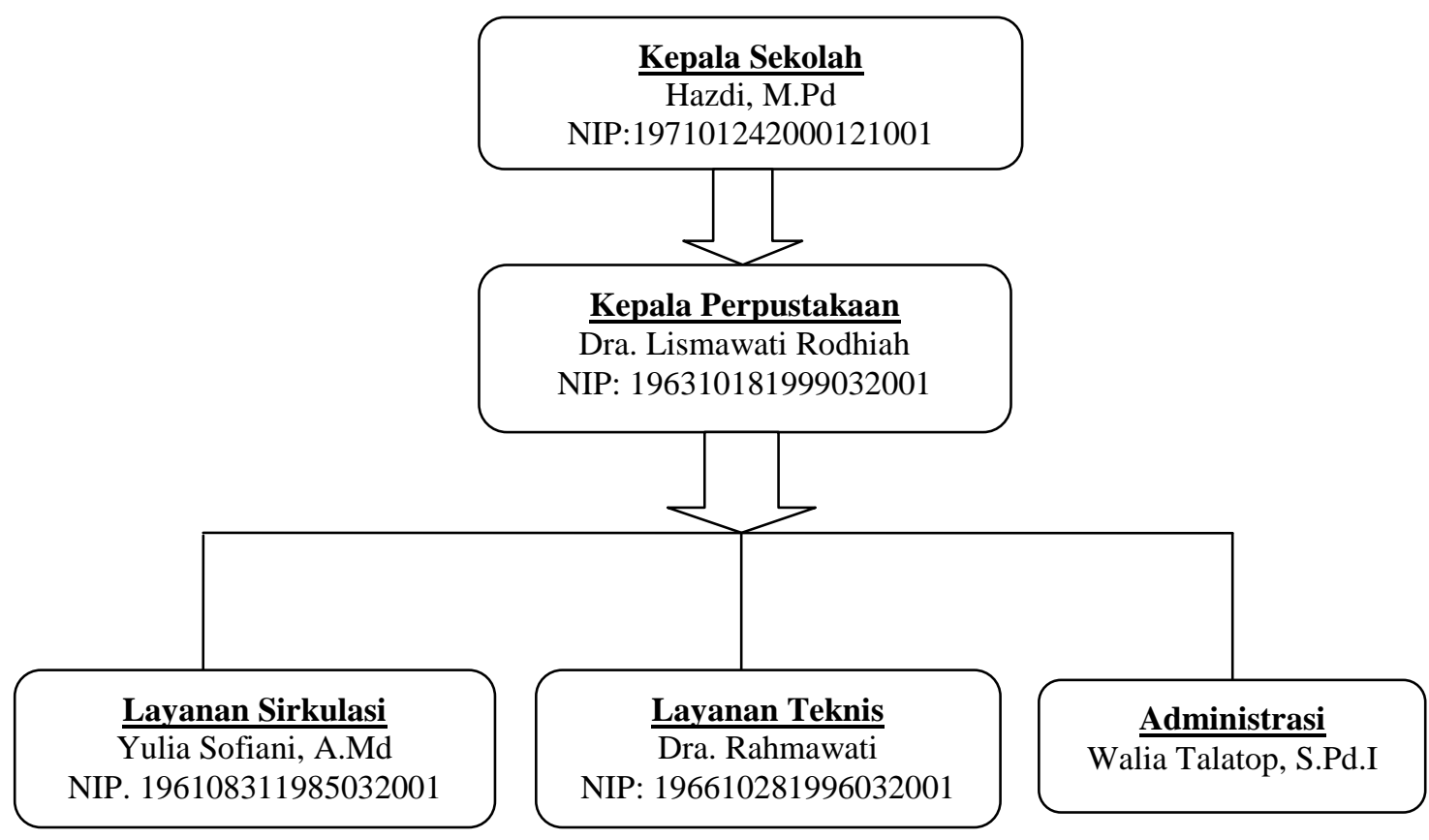

Gambar 1. Struktur Organisasi Perpustakaan MAN 2 Palembang T/A 2017-2018

e. Penggerak (Actuating) Perpustakaan MAN 2 Palembang

Pergerakan (actuating) dijalankan setelah adanya rencana dan pengorganisasian, sebab pergerakan merupakan pelaksanaan atas hasil-hasil perencanaan dan pengorganisasian. Berdasarkan hasil wawancara peneliti dengan Kepala Perpustakaan, mengenai implementasi proses kepemimpinan, pemberian dan pengarahan mengenai job description serta kebijakan yang diterapkan. Penjelasan kebijakan yang ditetapkan pada pelaksanaan perpustakaan ini malalui pertemuan tatap muka serta tinjauan langsung. Pelaksanaan teknis yang diberikan oleh Kepala Sekolh kepada koordinator perpustakaan yaitu kepala perpustakaan dilakukan dilakukan dengan sebagaimana bidang masing-masing.

f. Pengawasan Perpustakaan MAN 2 Palembang

Pengawasan sebenarnya merupakan proses untuk menjamin bahwa tujuan-tujuan organisasi dan manajemen tercapai. Ini berkenaan dengan cara membuat kegiatan-kegiatan yang direncanakan. Pada pokoknya pengawasan adalahkegiatan yang membandingkan atau mengukur apa yang sedang atau sudah dilaksanakan dengan kriteria, norma-norma, standar, atau rencanarencana yang sudah ditetapkan sebelumnya. Sedangkan menurut Engkoswara dan Komariah, pengawasan merupakan proses untuk 
mengetahui ada tidaknya penyimpangan dalam pelaksanaan rencana agar segera dilakukan upaya perbaikan sehingga dapat memastikan bahwa aktivitas yang dilakukan secara riil merupakan aktivitas yang sesuai dengan apa yang direncanakan. (Engkoswara, 2010 hal. 219).

Pelaksanaan tugas dan tanggung jawab di perpustakaan memerlukan pengawasan sehingga dapat diketahui efektivitas dan efisiensi penyelenggaraan perpustakaan, selain untuk memperoleh peningkatan kualitas. Dengan peningkatan ini diharapkan mampu menjamin aktivitasaktivitas yang dilakukan, sehingga memberikan hasil (produk) seperti yang diharapkan. Oleh karena itu perlu pengawasan dan evaluasi. Secara prosedural, evaluasi yang dilakukan kepala sekolah sebagai evaluator adalah untuk menindaklanjuti pelaksanaan manajemen perpustakaan berdasarkan kepada laporan/ 3 bulan/ 6 bulan dan akhir tahun ajaran oleh kepala perpustakaan.

\section{Kendala Pengelolaan Perpustakaan Perpustakaan MAN 2 Palembang}

Secara umum, perpustakaan sekolah/madrasah di Indonesia masih mengalami berbagai hambatan, sehingga belum bisa berjalan sebagaimana yang diharapkan. Hambatan tersebut berasal dan dua aspek, meliputi pertama aspek strutural, keberadaan perpustakaan sekolah kurang memperoleh perhatian dari pihak manajemen sekolah. Kedua aspek teknis, artinya keberadaan perpustakaan sekolah belurn ditunjang aspek-aspek bersifat teknis yang sangat dibutuhkan oleh perpustakaan sekolah seperti tenaga, dana, serta sarana dan prasarana (Manajemen perpustakaan sekolah, 2007).

Berdasarkan hasil penelitian tentang manajemen perpustakaan MAN 2 Palembang, diperoleh data dan informasi bahwa masih ada kendala yang menghambat proses manajemen di perpustakaan; 1) Masih belum tersedianya komputer dan layanan internet guna mendukung berjalannya pengelolaan dan pelayanan perpustakaan yang lebih baik 2) Pengetahuan tentang klasifikasi Islam yang seharusnya telah ditetapkan pada perpustakaan sekolah berbasis agama Islam, terlebih lagi Perpustakaan Madrasah Aliyah Negeri (MAN) 2 Palembang ini.

\section{KESIMPULAN}

Secara umum manajemen perpustakaan sekolah di Perpustakaan MAN 2 Palembang ini sudah cukup baik akan tetapi masih ada beberapa aspek yang harus tetap di perbaiki. Berikut kesimpulan mengenai fungsi manajemennya misalnya proses perencanaan pengelolaan perpustakaan MAN 2 Palembang ini lebih disudutkan kepada pendidikan pemakai yang dapat 
dilaksanakan pada tahun ajaran baru yang dilaksanakan bersamaan dengan masa orientasi siswa. Pengorganisasian dalam manajemen perpustakaan sekolah sama dengan perpustakaan sekolah pada umumnya. Pengorganisasian tersebut meliputi bentuk struktur organisasi serta pembagian kerja masing-masing staff perpustakaan. Proses penggerakan terkait proses kepemimpinan dilakukan oleh kepala sekolah. Penggerakan terkait job description dilakukan dengan instruksi Kepala Perpustakaan. Meskipun tidak ada standar pengawasan yang mengikat, sebagai bentuk tanggung jawab kepala perpustakaan membuat laporan setiap 6 bulan dan akhir tahun ajaran ditujukan kepada kepala sekolah. Selanjutnya dalam manajemen perpustakaan sekolah, ada kendala yang menghambat proses manajemen di perpustakaan; 1) Masih belum tersedianya komputer dan layanan internet guna mendukung berjalannya pengelolaan dan pelayanan perpustakaan yang lebih baik 2) Pengetahuan tentang klasifikasi Islam yang seharusnya telah ditetapkan pada perpustakaan sekolah berbasis agama Islam.

Berdasarkan hasil penelitian dan permbahasan pada uraian di atas maka peneliti memberikan saran bagi Perpustakaan MAN 2 Palembang sebagai berikut:

1. Mengoptimalkan proses klasifikasi berdasarkan perkembangan yang ada terutama penerapan klasifikasi islam.

2. Menyediakan beberapa komputer khusus untuk proses pengolaan serta komputer yang dapat diakses para pengguna.

\section{DAFTAR PUSTAKA}

Abdul Rahma Saleh, Badollahi Mustafa. 2013. Bahan Rujukan. Tangerang Selatan : Universitas Terbuka, 2013.

Abdul Rahman Saleh, Janti G. Sujana. 2009. Pengantar Perpustakaan. Jakarta : Sagung Seto, 2009.

Abdul Rahman Saleh, Rita Komalasari. 2013. Manajemen Perpustakaan. Tangetang Selatan : Universitas Terbuka, 2013.

-. 2013. Manajemen Perpustakaan. Tangerang Selatan: Universitas Terbuka, 2013.

Adib, Helen Sabera. 2016. Metodologi Penelitian. Palembang : NoerFikri, 2016.

Bafadal, Ibrahim. 2015. Pengelolaan Perpustakaan Sekolah. Jakarta : Bumi Aksara, 2015.

Basuki, Sulistyo. 2013. Pengantar Ilmu Perpustakaan. Tangerang Selatan : Universitas Terbuka, 2013. 
Dadang. 2012. Diktat: Pengantar Ilmu Informasi dan Dokumentasi. Palembang : Sn, 2012.

Darmono. 2007. Perpustakaan Sekolah: Pendekatan Aspek Manajemen dan Tata Kerja. Jakarta : Grasindo, 2007.

Engkoswara, Aan Komariah. 2010. Administrasi Pendidikan. Bandung: Alfabeta, 2010.

HS, Lasa. 2009. Manajemen Perpustakaan Sekolah. Yogyakarta: Pinus, 2009.

Lubis, Sir Andree Ma'arif Muhammad. 2019. Manajemen perpustakaan madrasah aliyah negeri pematangsiantar. Medan: Depatemen Perpustakaan dan Sains Informasi, 2019. http://repositori.usu.ac.id/bitstream/handle/123456789/12888/14070903 0. pdf? sequence $=1 \&$ is Allowed $=\mathrm{y}$.

Manajemen perpustakaan di madrasah aliyah negeri Yogyakarta. Arikunto, Suhaemin \& Suharsimi. 2013. 2, Yogyakarta: Graduate School, Universitas Negeri Yogyakarta, 2013, Vol. I. 2461-0550. DOI: https://doi.org/10.21831/amp.v1i2.2398.

Manajemen perpustakaan sekolah. Widiasa, I Ketut. 2007. 1, Malang: Perpustakaan Universitas Negeri Malang, 2007, Vol. 1. http://library.um.ac.id/images/gbjps/art02ktu.pdf.

Nana Danaprianta, Rony Setiawan. 2005. Pengantar Statistik. Yogyakarta : 2005, 2005.

Nihayati. 2013. Kajian manajemen perpustakaan madrasah aliyah negeri (MAN) se-kanupaten bantul Yogyakarta. Yogyakarta: Universitas Islam Negeri Sunan Kali Jaga , 2013. http://digilib.uinsuka.ac.id/7358/1/BAB\%20I\%2C\%20V\%2C\%20DAFTAR\%20PUST AKA.pdf.

Ningsih, Rahayu. 2007. Pengelolaan Perpustakaan. Yogyakarta: Graha Ilmu, 2007.

NS, Sutarno. 2006. Manajemen Perpustakaan: Suatu Pendekatan Praktis. Jakarta : 2006, 2006.

Oka, Gde Putu Arya. 2017. Media dan Multimedia Pembelajaran. Yogyakarta : Deepublish, 2017.

Perpustakaan Nasional Republik Indonesia. Standar Perpustakaan Nasional. Perpustakaan Nasional Republik Indonesia. [Online] [Cited: Mei Senin, 2018.] http://www.pnri.go.id/iFileDownload.aspx?ID=Attachment\%5CPedom an\%5Cstandar\%20perpustakaan-sekolah.pdf.

Prastowo, Andi. 2013. Manajemen Perpustakaan Sekolah. Jogjakarta : Diva Press, 2013. 
Tik Ilmeu, VOL.3, NO.2, 2019|145

Rodin, Rhoni. 2018. Implementasi fungsi manajemen dalam pengelolaan perpustakaan. Yogyakarta : Suluh Media, 2018.

Sugiyono. 2010. Memahami Penelitian Kualitatif. Bandung : Alfabeta, 2010. 